\title{
大学教育における教授・学習過程と学生の発達過程の関連 (13)
}

\author{
佐藤公代 \\ (愛媛大学 教育学部) \\ Key words: 評価の効用、評価の限界、メールによる指導
}

\section{（問題と目的）}

佐藤の「大学教育における教授・学習過程と学生の発達過 程の関連 $\left.(1) ＼mathrm{~ ～(~} \begin{array}{ll}1 & 2\end{array}\right) 」 の 一$ 連の研究から、今回は、メー ルによる卒業論文の指導に関する効用と限界について考える ことにする。 I T 時代においてメールは欠かせないものであ るかも知れないが、指導に関しては果たしてどんな効果をも たらすのであろうか。それともどんなマイナス効果になるの だろうか。そんな疑問から、偶然起こった事態を考察してみ ることにする。

放送大学の客員教員として、6 年間の間に 5 人の卒業論文 を指導してきた。その間、1人の人がメールによる指導を要 望してきた。初めての経験で、どのようにしたらよいかを考 えてみた。相手からの論文を点検し、メールで返信し、そこ からまた、やりとりをして仕上げていく。

仮説は以下の通りである。

（1）効用よりも限界の方に問題点が多いだろう。

（2）二ュアンスの限界が見られるであろう。

(方法)

1）期日：2006年 7 月〜 10 月

2 ) 対象者：卒業論文（文献研究）を書く人、1人

3 ）手続き：7 回のメールを分析して、効用と限界を考える 資料を取り出す。

(結果と考察)

添付ファイルを使ったことのない学生だったので、メール の送受信が出来るから゙うか心配で送られてきたメールに対す る返信は、「届きました。卒論原稿も見れました。書き直した ものを送って下さればまた見ます。無理をなさらないでお励 み下さい。」である。問題意識がはっきりしない段階ではじめ た研究なので、学生の自主性にまかせ、送られてきた原稿を 手直しする形態をとる。

$<1>「 7$ 月に指導いただいた笑いに条件をつけると結論が 出しや寸いと言われていたので条件毎に分けて検討し直しま した。また、引用文献の巻末の表示、本文での引用表記も修 正しました。まだまだ、まとまりがないかと思いますが、ご 指導お願いします。」に対し、「前よりは出来ていると思うし、 勉強もしているなと思います。ただ、まとめかたとして、文 献研究なので、図表などはいらないと思います。自分でデー 夕をとったのなら研究方法とか、結果・考察など必要ですが、 人のデータなら、そんな書き方はしない方が良いです。序章 に問題意識（なぜそのような研究をするのか）、本論には笑い の効用と限界について、先人の研究をまとめていき、最後の 結論で自分の意見を述べておくのです。そんなまとめ方をす ると読みやすいと思うのですが、いかがでしょうか。いつか、 松山に来られる時がありましたらどうぞお寄り下さいませ。」 と返信した。

$<2>$ 「用文献を減らし、要約しました。要約部分は、参 考文献として表示しておくと問題ないでしょうか。筆者の考 察部分は最後のまとめに書きました。枚数がかなり減ってし まったため違った人の考えも加えたいと思うのですが、文献 上引用されたものをこの研究でそのまま引用することは避け
た方がいいでしょうか。（引用の引用）質問ばかりですみませ ん。ご指導お願いします。」に対し、「前よりはよくなってい ますが、もう少し頑張りましょう。1 . 要約は良いと思いま す。参考文献に入ります。 2 . 引用の引用を孫引きと言いま すが、文献が手に入らない場合などを考えて孫引きをしてし まう場合があります。卒論程度ならやっても良いと思います。 3. 心理学の学会誌を見て書き方をま社た方が良いかも知れ ません。4 . 筆者の考察部分や提案を言いたいための先人の 研究を読んだり、引用したりするのですから、そこにいたる までに論理的に書かないといけないかと思います。 5 ，節の ところに名前 (名字) がでていますが、その名前は取っても 良いと思います。6.テーマ、目次の付け方を直さないとい けないのですが、もう少し、内容を見てからにします。 7 . 今日はとりあえず、ここまでとします。9，10月色々悩む かも知れませんが、みなさん、そこを通過して良い論文を書 いているのです。数回で完成する人などいないと思います。 お体にお気をつけてお励み下さい。」返信した。

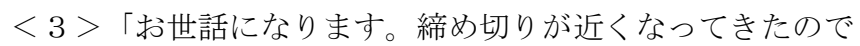
すが、まだまだ手直しが必要かと思います。特に気になると ころが、1. 第 1 章の先行研究はどれぐらいあげるべきです か。2. 孫引きは原書も表記されている場合は表記するべき ですか。その他お気づきの点ご指導お願いします。」に対し、 「ごくろうさまです。以前よりは良くなっていると思いますが、 まだ直させて下さいね。1 . 先行研究の数は決まっていませ ん。自分が論じたいことで参考になるものがあったら上げて 良いと思います。ただ枚数があるので、そこはうまく切り上 げないといけないかと思います。2，原書もあるならあげて も良いですが、枚数の関係で多くなるようだったら省いても 良いです。3．テーマについては、もう少し内容が出来てか ら直します。 4 . 目次の先行研究の所に外人の名前があげら れていますが、名前をあげずに、第 1 節のように表示規則と か、何か事柄を上げた方が良いかと思います。別に外人の名 前が重要という事ではないと思いますので。5。「」が長い ような気がします。6，所々、主語と述語のつながりが悪い ところがあります。よく読んで直したら良いと思います。例

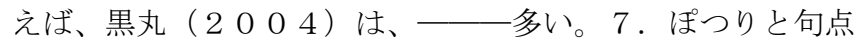
がついているところがあったりします。例えば、ここに私た ちが笑顔をする理由。顔と声ともに表現することができる感 情。今日は以上です。お体をお大事にお励み下さい。」と返信 した。

$<4>「 大$ 変お世話になります。まだまだたくさん修正が必 要と思います。特に、1．読んでいて分かりづらいところ、 2. 全体的なバランスが気になります。その他お気づきの点 ご指導お願いします。」に対し、「どうも有り難うございまし た。以前より、はるかによくなりました。自分で指摘したと ころ、私も気になりましたが、あとは、枚数や細かい所など の訂正などで大枠はそれで良いと思います。あと、もう少し ですが、お体にお気を付けてお励み下さい。」と返信した。 $<5><6>7>$ は紙面の都合上省略する。

仮説（1）（2）について支持されるやりとりが見られる。

( S A T O K i m i y o ) 